\title{
A Study of Relationship between Occupational Stress and Psychological Well-Being among Private and Public Sector Employee
}

\author{
Tarlika L Zalawadia ${ }^{1} *$
}

\section{ABSTRACT}

The present investigation was to compare the relationship between occupational stress and psychological well-being among Private and Public Sector Employee. The sample consisted of 120 male and female Private and Public Sector Employee working at various manufacturing industries in Rajkot city. Srivastava \& Singh's (1984) “Occupational stress Scale” and Bhogle \& Prakash's (1995) "Psychological will-being Questionnaire” were administrated to them. Karl Pearson's correlation method yielded negative and significant correlation between occupational stress and psychological well-being among Private and Public Sector Employee. Moreover highstress group has been found to have higher correlation between occupational stress and psychological well-being than moderate stress group and low stress group.

Keywords: Occupational Stress, Psychological Well-being, Private-Public Sector Employee

Stress is present in every field and stage of life. We experience stress continuously throughout our life in family, occupation, either in social or economic activities; perhaps that's why the modern age is identified as "The Age of Anxiety and Stress". Almost all people at some time in their life experiences stress which is associated to their occupation. But some people suffer higher level of stress. Which factors make job stressful? As Sorafino (2002) pointed out, the demands of the task can produce stress in two ways. First the workload may be too high; studies have found that excessive workload is associated with increased rate of accidents and health problems (Mackay\& Cox, 1978; Quick et al., 1997). Second, some kinds of job activities are more stressful than others and they are linked with well-being. Some other factors make job stressful, for example - role ambiguity, role conflict, poor peer relation, strenuous working condition, insecurity etc. Occupational stress refers to the complex, multidimensional effects of professional life of working person (Cooper \& Payne, 1978; Karasek \& Theorell, 1990). Recent

\footnotetext{
${ }^{1}$ Associate Professor, Smt. R. R. Patel Mahila Arts \& Commerce College, Rajkot, Gujarat, India *Responding Author

(C) 2016, T Zalawadia; licensee IJIP. This is an Open Access Research distributed under the terms of the Creative Commons Attribution License (http://creativecommons.org/licenses/by/2.0), which permits unrestricted use, distribution, and reproduction in any Medium, provided the original work is properly cited.
} 


\section{A Study of Relationship between Occupational Stress and Psychological Well-Being among Private and Public Sector Employee}

investigations have directed attention too many other stress related occupational problems (Appley \& Trumbull, 1986). Characteristics such as subjective comfort and well-being, emotional reactions and job satisfaction, self-esteem and personal resources for copying and adaptation have moved from the periphery to the center of interest in empirical studies of stress in the work place.

Babajide, E. O.; Akintayo, I. (2011), found that significant difference not found in the perception of male and female respondents on the influence of occupational stress on their psychological well-being. Based on the findings of their study, it is recommended that organizational support system that could combat the physical, social and psychological effects of occupational stress on workers' psychological well being and their behavior should be provided at workplace. Also, industrial counseling services should be introduced in work organizations in order to provide therapeutic services that tend to foster reduction in the effects of occupational stress on workers' psychological well being. Malek, M. D. A., Fahrudin, A. and Mohd Kamil, I. S. (2009) survey on 617 Malaysian firefighters. The moderating effect of work motivation and coping strategies on job satisfaction and psychological well-being. The result suggested that coping strategies and work motivation are one of the potential moderating variables between sources of stress and job satisfaction.

\section{Objectives:}

1. To study of occupational stress and psychological well-being among Private and Public Sector Female Employee.

2. To study of occupational stress among Private and Public Sector Male and Female Employees.

3. To study of psychological well-being among Private and Public Sector Male and Female Employee.

\section{Sample:}

The study was conducted on 120 Private and Public Sector Female Employee working in various manufacturing factories in Rajkot city. In which 60 Female and 60 Male employees were selected. The educational attainment of the participants ranged from diploma to master degree.

\section{Tools:}

Following psychometric tools were employed in the present investigation.

1. Occupational stress scale: Abridged version of Shrivastav \& Singh's (1984) "occupational stress scale" translated in to Gujarati language by Dadhaniya (1988) was used to measure the occupational stress of employee. The scale comprises 46 items to be rated on 5-point scale, relating to various dimensions of occupational stress. The scale has acceptable level of reliability and validity as reported by Shrivastav \& Singh. 
A Study of Relationship between Occupational Stress and Psychological Well-Being among Private and Public Sector Employee

\section{2. $\quad$ Psychological Well-being Questionnaire:}

To measure the psychological well-being in employee "Psychological Well-being Questionnaire” by Bhogle and Prakash (1995) was used. The questionnaire contains 28 items with true and false response alternative. It covers 12 dimensions of psychological well-being. The maximum possible score is 28 and minimum is zero. High score indicates high level psychological well-being. The test-retest consistency coefficient is 0.84 . The author has reported satisfactory validity of the questionnaire.

\section{RESULTS AND DISCUSSION}

As the aim of present research was to study the relationship between occupational stress and psychological well-being among Private and Public Sector Female Employee were divided into three groups based on their occupational stress score (low, moderate and high stress groups). Karl Pearson's correlation method was used to identify relation between occupational stress and psychological well-being among the employee of these sub-groups. The results are presented in table -1 .

Table - 1 Correlation of occupational stress and psychological well-being among Private and Public Sector Female Employee

\begin{tabular}{|c|c|c|}
\hline Stress Groups & N & r \\
\hline Low stress & 39 & $0.52^{* *}$ \\
Moderate stress & 46 & $0.63^{* *}$ \\
High stress & 35 & $\mathbf{0 . 7 6 * *}$ \\
\hline
\end{tabular}

$* * P<.01$

Table no. 2, Occupational stress among Private and Public Sector Male and Female Employees

\begin{tabular}{|c|l|c|c|c|c|}
\hline No & Group & N & Mean & SD & t value \\
\hline 1 & Male Employee & 60 & 11.04 & 0.84 & \multirow{2}{*}{$4.54^{*}$} \\
\hline 2 & Female Employee & 60 & 9.54 & 1.59 & \\
\hline
\end{tabular}

*Significant at 0.05 Level 
A Study of Relationship between Occupational Stress and Psychological Well-Being among Private and Public Sector Employee

Table no. 3, Psychological well-being among Private and Public Sector Male and Female Employee

\begin{tabular}{|c|l|c|c|c|c|}
\hline No & Group & N & Mean & SD & t value \\
\hline 1 & Male Employee & 60 & 7.56 & 1.20 & \multirow{2}{*}{0.36} \\
\hline 2 & Female Employee & 60 & 7.44 & 1.34 & \\
\hline
\end{tabular}

\section{DISCUSSION}

The result indicates that there is correlation between occupational stress and psychological wellbeing among the Private and Public Sector Female Employee of low stress group correlation is ( $\mathrm{r}$ $=0.52$ ), among the Public sector employee of moderate stress group correlation is $(\mathrm{r}=0.63)$, and among the Private sector of high stress group correlation is $(r=0.76)$. These correlations are significant at 0.01 level. Hence, we can say that there is negative correlation between occupational stress and psychological well-being among the Private and Public Sector Female Employee.

Moreover, it is found during comparison of correlations of all three groups that the Female employees of high stress group have high negative correlation between occupational stress and psychological well-being than other groups. Thus, it can be said that as occupational stress increases psychological well-being decreases in female employee.

\section{CONCLUSION}

If we analyze above table no 2 and 3, we can see that as per table no 2, Male employee better then Female employee in Occupation Stress and Significant level at 0.05 level. As per table no. 3, Male employee better then Female Employee in Well-Being but no any significant difference with both of group. Also above results we can say that private sector employees live with many challenges that develop stress in their lives directly or indirectly. The possible reason of this situation is the stressful condition of a person is a disturbing factor in solving the problems of his professional and personal life. The stress reduces the emotional stability of a person and reduces mental capability (Smith \& Lazarus, 1993). Male employees are more affected with both the matters, so because of continuous occupational stress, his psychological well-being may be dangerously affected. Pattanayak et al., (1993).

\section{Acknowledgments}

The author appreciates all those who participated in the study and helped to facilitate the research process.

\section{Conflict of Interests}

The author declared no conflict of interests. 


\section{REFERENCES}

Appley, M.H., \& Trumbull, R. (1986). Development of the stress concept. In M.H. Appley \& R. Trumbull (Eds.), Dynamics of stress (pp. 3-18). New York : Plenum.

Babajide, E. O.; Akintayo, I. (2011) Occupational Stress, Psychological Well Being and Workers' Behavior in Manufacturing Industries in South-West Nigeria. International Journal of Management \& Innovation . 2011, Vol. 3 Issue 1, p32-42. 11p. 2 Charts.

Bhogle, S. \& Jay Prakash, I. (1995). Development of psychological well-being questionnaire, Journal of Personality and Clinical Studies, Vol. 11 (1\&2), pp-5-9.

Cooper, C.L. \& Payne, R. (1978). Stress at Work. Chichester: Wiely. Karasek, R. \& Theorell, T. (1990).Healthy Work, Stress, Productivity and the Reconstruction of Working Life. New York : Basic Books.

Frese, M. (1986). Coping as a moderator and mediator between stress at work and psychosomatic complaints. In M.H. Appley \& R. Trumbull (Eds.), Dynamics of stress (pp. 183-206). New York : Plenum.

Karasek, R., \& Theorell, T. (1990). Healthy work, stress, productivity, and the reconstruction of working life. New York : Basic Books

Malek, M. D. A., Fahrudin, A. and Mohd Kamil, I. S. (2009), Occupational Stress and Psychological Well-Being in Emergency Services. Asian Social Work and Policy Review, 3: 143-154. doi:10.1111/j.1753-1411.2009.00030.x

Pattanayak,B., Mishra, S.K. \& Mishra,P.K. (1993). Psychological well-being and Organizational Commitment, a study of public sector, Indian Journal of applied Psychology (30) 2, 2431.

Quick, J.C., Quick, J. D., Nelson, D. L. \& Hurrell, J.J.(1997). Preventive Stress Management in Organizations. Washington, DC: American Psychological Association.

Sarafino, E.P. (2002). Health Psychology: Biopsychosocial Interactions, (4 ${ }^{\text {th }}$ Eds.). New York: John Wiley \& Sons.

Smith, C.A. \& Lazarus, R.S. (1993).Appraisal components, core relational themes and the emotions. Cognition and Emotions. 7, 233-269.

How to cite this article: Tarlika L Zalawadia (2016), A Study of Relationship between Occupational Stress and Psychological Well-Being among Private and Public Sector Employee, International Journal of Indian Psychology, Volume 3, Issue 4, No. 68, ISSN:2348-5396 (e), ISSN:2349-3429 (p), DIP:18.01.217/20160304, ISBN:978-1-365-39398-3 